\title{
A DOUTRINA DA EdUCAÇÃO DIVINA DO HOMEM NA BÍBLIA GREGA
}

\author{
THE DOCTRINE OF DIVINE EDUCATION OF MANKIND \\ IN THE GREEK BIBLE
}

ÉLCIO VERÇOSA FILHO ${ }^{(*)}$

\begin{abstract}
RESUMO
$\mathrm{O}$ artigo busca recuperar um importante fundamento na constituição da teologia da história do cristianismo patrístico, a noção de educação providencial da humanidade, investigando as suas origens na tradução grega da Bíblia hebraica, a Septuaginta, que remonta ao judaísmo alexandrino do século II a.C. O objetivo é fornecer insumos para a história da noção de Providência divina em certa tradição de pensamento do cristianismo oriental, de Irineu de Lyon a Orígenes e além, propondo uma leitura talvez inédita, tanto no âmbito nacional quanto internacional, da sua elaboração como educação divina (Paideia) na Bíblia grega. Com esse fim, o ensaio oferece uma leitura em profundidade da tradução grega de determinadas passagens centrais do Deuteronômio que fazem referência à ação divina como processo educativo, passando a discutir em seguida as mesmas visões nos novos textos - depois canônicos - criados pelos judaizantes helenizados de Alexandria a partir do século III a.C., como a "Sabedoria de Salomão" e o "Eclesiástico de Ben Sirach".

Palavras-Chave: Teologia da História. Paidéia. Providência. Patrística. Bíblia Grega. Judaísmo Alexandrino.

ABSTRACT

This essay seeks to retrieve an important foundation in the constitution of the theology of history in patristic times, i.e., the notion of the providential education of Mankind, uncovering its origins in the translation of the Hebrew Bible to the Greek, the Septuagint, which can be traced back to the Alexandrian Jewish community of the Second Century B.C. The aim is to contribute to the history of the development of the notion of Divine Providence in a particular strand of Eastern Christian thought, from Irinaeus to Origen and beyond. In order to achieve that, the essay offers an in-depth reading of the Greek translation of certain key passages in the Deuteronomy that point to a pedagogical interpretation of Divine Action, then discussing the more developed versions of that view in the new texts authored by the Hellenized Jews of Alexandria around the $3^{\text {rd }}$ Century B.C, such as "The Wisdom of Salomon" and Ben Sirach's "Ecclesiasticus".
\end{abstract}

KEYWORDS: Theology of History. Paideia. Providence. Patristics. Greek Bible. Alexandrine Judaism.

\section{INTRODUÇ̃̃O}

A despeito da absorção mais ou menos profunda da paideia grega, e principalmente da filosofia, operada pelas formas mais altas do cristianismo (em especial a teologia), sempre existiu, pelo menos da parte dos autores cristãos, a consciência de um abismo, de uma diferença essencial entre filosofia

(*) Doutor em Ciências da Religião pela Pontifícia Universidade Católica de São Paulo. Pós-Doutorando em Filosofia pela USP, com bolsa FAPESP. Professor de Filosofia e Ética da FACOM/FAAP. Atua principalmente nos seguintes temas: teoria da religião, teologia mística, patrística, Filosofia da Religião, Filosofia política. Trabalha também como roteirista, diretor de cinema e publicidade e tradutor de publicações especializadas em Filosofia Antiga e Religião. E-mail: vercosafilho@gmail.com 
e teologia (exatamente o que, em última instância, dá origem à ideia da "subordinação" da disciplina filosófica1), um contraste que nasce das diferentes visões acerca da meta (em ambos os casos, como veremos abaixo, indicada pela palavra "sabedoria") à qual se dirige o esforço de assimilação que ambas, propondo-se como fim e perfeição da vida humana, pretendem operar ${ }^{2}$ : a paideia filosófica, em especial aquelas correntes que sofreram a influência do platonismo, tinha como seu mais alto anelo integrar o adepto, pela "conversão" progressiva da alma ao uno (sua "simplificação", como mais tarde dirá Plotino) operada pelo exercício da dialética, à perfeição da divindade supraceleste (o reino divino das ideias e notadamente a ideia do Bem), princípio da ordem e beleza do Todo, que ao mesmo tempo ela pesquisa e venera, e que habita (através de algo como uma centelha) na alma, sendo em última análise passível de apropriação3; a teologia nascente, por sua vez, tinha como ideal máximo a união com o Deus trinitário, que, como diz Irineu, tornou-se visível em seu Filho, mas que armou a sua tenda na escuridão. No primeiro caso, a sabedoria, equiparada ao ápice da formação da personalidade, é o fim esperado de um esforço técnico (a dialética), que, por sua própria dinâmica interna, é visto como autônomo e naturalmente capaz de produzi-la4; no segundo, identificada em última instância ao próprio Deus incriado, ela é, como este mesmo, radicalmente inatingível para a criatura, podendo ser apenas o resultado de uma condescendência, em última análise uma concessão.

Assim, a primeira paideia, filosófica (que, em seus próprios termos, também é uma "paideia divina"), sendo eminentemente "ativa" 5, e estruturando-se sobre o modelo clássico da techne (ainda que ela pretenda resumir e ultrapassar todas as outras technai), estabelece-se, por esse motivo mesmo, sobre uma total confiança nas possibilidades humanas; enquanto a segunda, que conduz à sabedoria do Deus vivo, opera uma radical inversão de perspectiva, sendo marcada por certo grau de passividade e pela dependência daquele que busca

\footnotetext{
${ }^{1}$ Ver, a propósito, ORÍGENES, Carta Gregório Taumaturgo (Epist. Ad Taumat.), a primeira proposição da filosofia como theologiae ancillae.

2 Isso é claro já no Século II, como mostra JUSTINO ROMANO, Diálogo com o judeu Trífon, caps. IV-VII.

3 Para a dialética como conversio ad unum ver REALE, 1994, p. 164 e ss.

4 Há, no entanto, a visão expressa na famosa carta VII (341C-D), que aproxima o termo da anábase filosófica (o conhecimento/assimilação à ideia do Bem) de uma espécie de intuição mística, um conhecimento por comunhão, atingido através de algo semelhante a uma graça. Ver LOUTH, 1981, p. 13. Como toda interpretação "mística" do pensamento de Platão, essa interpretação da Carta VII é bastante problemática, deve-se dizer.

5 O termo é problemático, posto que para os filósofos a vida filosófica é justamente o que define a "vida contemplativa" em oposição à vida "ativa" dos cavalheiros que se desenvolve na cidade e, portanto, no exercício da política. Assim, "ativa" aqui quer dizer "suficiente", não dependente da "passividade" que caracteriza a graça ou, como foi dito, da "condescendência” necessária à transformação do homem por e em Deus.
} 
em relação ao objeto do desejo, que desse modo assume a iniciativa e torna-se, na prática, o verdadeiro sujeito, em última análise o verdadeiro buscador.

Apesar do papel central que teve naquela forma mais alta de cristianismo erudito, que a posteridade veio a denominar de teologia, essa inversão radical de perspectiva, a proposição nos termos que acabam de ser descritos de uma conversio ou metanoia, não foi, no mundo antigo, apanágio dos cristãos. Como exemplo do que ocorreu com o conceito de Providência, sobre o qual tratei em outro lugar, também nisso o judaísmo alexandrino aparece como um importante precursor. Por causa dele, mais especificamente por causa da Bíblia Grega e dos textos produzidos originalmente no contexto da nova metrópole egípcia, a noção de paideia recebida pelo cristianismo primitivo, e que ele usou para significar a contemplação da sequência dos tempos históricos referida a Deus, estava longe de ser exclusivamente filosófica ou “cultural”. Antes, ela se originava, pelo menos em parte, do desenvolvimento prévio de uma visão independente e profundamente religiosa de paideia providencial que não pode ser reduzida, como parece querer Jaeger, à mera noção de castigo ou punição ${ }^{6}$.

Seja como for, a percepção cristã de uma pedagogia em operação na revelação e na condução soberana da história pelo Deus vivo já se encontra ali bastante desenvolvida, especialmente no Deuteronômio e nos textos mais recentes da literatura sapiencial. E, com efeito, se, como mostra Jaeger, a principal característica da nova paideia era a proposta de formar o homem não mais a partir da teologia dos poetas e filósofos gregos, que já não gozavam de autoridade, mas no molde da revelação divina, esse molde é, em termos históricos concretos, o texto da LXX, a versão grega da Bíblia que, com autoridade de texto inspirado7, forjou a forma mentis (ou forma animae, como

\footnotetext{
${ }^{6}$ JAEGER, 1998, p.40

7 A célebre "legenda" reproduzida numa carta do Pseudo-Aristeu (séc. II a.C.) que dá conta da produção miraculosa do texto da LXX, segundo a qual setenta e dois sábios, seis de cada tribo de Israel, teriam traduzido em separado, por encomenda do rei do Egito, Ptolomeu Filadelfo, os textos hebraicos, obtendo exatamente o mesmo resultado, nada tem de gratuita: o que ela faz é corroborar a percepção de autoridade com que, nos meios cristãos e judeus helenizados, a tradução se revestiu desde o princípio (cf. SESBOÜÉ, 2002, p.61: "A Igreja cristã acolheu espontaneamente o texto da LXX, como atesta o fato principal de os escritos do Novo Testamento citarem geralmente o Antigo segundo essa tradução grega e atribuírem espontaneamente a tais escritos a autoridade de 'Escrituras', isto é, de testemunho inspirado da Palavra de Deus"), algo que se pode constatar até mesmo em época bem tardia e num outro contexto cultural, como aquele retratado na Cidade de Deus, de AGOSTINHO (cf. De Civ. Dei. XVIII, 42-44). Nesses capítulos da sua obra-prima, Agostinho oferece uma explicação providencial, relacionada ao cristianismo, para o milagre contado na legenda que inicia esta nota, que me parece nos colocar no caminho correto para a apreensão do significado da tradução grega da Bíblia e sua assunção como modelo divino de formação pelos primeiros autores cristãos: "E não é de se estranhar [i.e. a "perfeita unanimidade da tradução"], pois em todos [os tradutores] atuava o mesmo espírito. Deus, com esse admirável dom, quis encarecer aos gentios que eles algum dia creriam, como já vemos cumprido, na autoridade da Escritura como obra divina, não humana”. Vale observar que a convicção na autoridade divina da tradução da LXX leva
} 
se queira) dos primeiros cristãos, uma vez que, do ponto de vista histórico, foi através desse texto e suas categorias que eles tiveram, de facto, acesso ao que acreditavam ser a palavra de Deus ${ }^{8}$. É de se notar que, a partir desta dupla influência, Atenas e Jerusalém, filosofia e Escritura, que de fato já se fazia sentir, e inevitavelmente, na própria teologia da LXX (produto do cruzamento pioneiro entre os dois mundos em Alexandria), as elaborações posteriores da paideia tendem a trabalhar em dois sentidos, conceitualmente distintos, mas, na prática, complementares: um propriamente religioso ou teológico - a interpretação pedagógica da ação sobrenatural da Providência - e outro que poderíamos chamar de "ideológico ou cultural", equivalente à formação do homem histórico, concreto, através do ensinamento religioso baseado nos dados da revelação e necessariamente endereçado a uma determinada comunidade política e social, uma dupla característica que ficará, espero, bem evidenciada na discussão que se segue.

\section{A PAIDEIA No DEUTERONÔMIO}

A doutrina da paideia presente na Bíblia grega9 pode ser resumida num dos adágios mais célebres de toda a Escritura: ápxǹ бoфías фóßos kupiou - “O Temor

\footnotetext{
Agostinho à postulação de uma doutrina da "revelação progressiva" capaz de deixar de cabelo em pé os mais fervorosos adeptos do método histórico, assim como os defensores da interpretação literal da Bíblia, naturalmente. "Pois, segundo ele, o mesmo Espírito que assistiu os profetas quando compunham as Escrituras, animava os setenta homens quando as traduziam. E, fora de dúvida, poderia muito bem, com autoridade divina, dizer outra coisa, como se os profetas houvessem dito ambas as coisas, porque ambas diria o mesmo espírito. Poderia dizer de várias maneiras a mesma coisa, a fim de que, se não as mesmas palavras, ao menos descobrissem o mesmo sentido os bons entendedores. Poderia, além disso, acrescentar ou omitir algo, para mostrar-nos não haver o tradutor sido escravo das palavras, mas do poder divino, que o animava e dirigia na obra” Ibid. XVIII 43 (grifo meu). No mesmo capítulo Agostinho ainda fala sobre as discrepâncias de fato entre os dois textos, o original hebraico e a sua tradução alexandrina, explicandoas como dois momentos diferentes, mas da mesma forma legitimamente divinos, da revelação total: "Se, por conseguinte, como deve ser, não consideramos os homens que compuseram as Escrituras senão como instrumentos do Espírito de Deus, diremos que as coisas que se encontram no original hebraico e não se encontram nos Setenta, quis o espírito divino dizê-las pelos profetas e não por estes. E quanto há nos Setenta e falta no códice hebraico o mesmo Espírito preferiu dizê-las por estes, mostrando, deste modo, haverem uns e outros sido profetas. Assim, disse umas coisas por Isaías, outras por Jeremias, outras por este ou aquele profeta ou disse doutra forma as mesmas coisas por este ou por aquele. Enfim, quando em ambas as fontes se contêm as mesmas coisas, quis o Espírito servir-se de uns e de outros para dizê-las, mas de tal modo que aqueles profetizassem e estes lhes interpretassem as profecias [dessa forma Agostinho justifica as evidentes interpretações teológicas que se insinuam em algumas das traduções da LXX, como veremos a seguir]. O mesmo Espírito que assistiu os primeiros, estabelecendo perfeita concordância entre eles, apareceu nos segundos, conduzindo-lhes a pena para fazerem traduções idênticas”. Para uma discussão da fonte, a carta do Pseudo-Aristeu, cf. DORIVAL, 1988: p. 40 e ss.

8 Algo que é muito pertinentemente sublinhado por Marguerite Harl na Introdução a uma coletânea de seus estudos. Segundo ela, a Bíblia grega era "a forma autêntica do Antigo Testamento para a Igreja primitiva” HARL, 1993, p. 21. De outro lado, a falta dessa visão da importância fundamental da LXX na formação do pensamento dos padres parece ser o grande (e quiçá único!) handicap do magistral estudo de Jaeger sobre o Cristianismo Primitivo e a Paidéia Grega (1998).

9 A edição da Bíblia grega usada para as citações desse artigo é primariamente a edição grego-inglês de BRENTON, 1900 cotejada com a versão autorativa de Göttingen (67 volumes entre 1931-2006, agora
} 
do Senhor é o princípio da Sabedoria”, um ensinamento que transcende a literatura sapiencial de tempos mais recentes e que conhece a sua primeira enunciação no Salmo 111, 10 (=110 da Septuaginta). Mas, ao que tudo indica, a interpretação propriamente pedagógica dos atos divinos faz a sua primeira aparição na "História deuteronômica", uma série de textos compostos no tempo do exílio babilônico que abrangem o próprio Deuteronômio e partes de Samuel e do Livro dos Reis e buscam fornecer uma perspectiva teológica aos eventos fundadores descritos narrativamente no livro do Êxodo, aquilo que, em sua essência, corresponde à assim chamada “experiência de Israel”.

Esses primeiros textos são, com efeito, os mais indicados para corrigir a opinião muito difundida de que a doutrina da paideia na Bíblia grega se resume à estreita noção de castigo ou punição divina, inclusive por serem capazes de colocar em contexto o que, em cada caso específico, estas expressões querem conotar $^{10}$. Sem dúvida em mais da metade das ocorrências o termo "paideia" é usado, estrito senso, nesta acepção; mas aquilo que de modo mais amplo o seu sentido propriamente teológico pretende sugerir só pode ser apreendido através de uma análise cuidadosa dos textos específicos em que o termo aparece, levando em conta principalmente os muitos paralelismos e interseções existentes entre eles ${ }^{11}$. Penso que o que quero dizer ficará claro logo na sequência do texto.

disponível eletronicamente) e, quando disponível, com La Biblie d'Alexandrie, publicada pelas Éditions du Cerf por Marguerite Harl e Gilles Dorival (1981-).

10 Esta era, conforme indicado mais acima, a opinião de Jaeger, assim como também, em certas passagens, e muito estranhamente, dos editores da Bíblia de Jerusalém. Para uma visão mais ampla da LXX como um todo, que inclusive serviu de inspiração para a minha própria exegese dos textos, ver os estudos filológicos dirigidos por Marguerite Harl, coordenadora da edição da Bíblia grega em língua francesa, a Bible d Alexandrie. Ver, em especial, a sua introdução a esta edição na obra conjunta (Harl, Dorival, Munnich eds., 1988.

${ }^{11}$ Num levantamento não exaustivo, que não pretende ter qualquer valor estatístico, fui capaz de encontrar na Bíblia grega um total de 51 ocorrências do termo "paideia" (que na grande maioria das vezes traduz o termo hebraico mûsar, mas também pode traduzir outros vocábulos, como towkechah e lamad - cf. BJ p. 2099 n.a) e seus derivados linguísticos imediatos (verbos, advérbios, etc.), divididos em três grandes blocos de significação: em primeiro lugar, com mais da metade do número total de ocorrências (27), estão as instâncias que denotam "castigo", "punição", "repreensão" divina aplicada ao homem com a intenção expressa (a maioria absoluta das vezes) ou tácita de "corrigi-lo", "emendá-lo", "regenerá-lo" e "convertêlo", o que já indica por si mesmo a existência de um "projeto" ou de uma "estratégia” pedagógica da parte da divindade que castiga; depois, em menor número, vêm as ocorrências que indicam a pura e simples "instrução" ou "educação" pela palavra, seja de Deus diretamente (quer dizer, na Lei e no Pentateuco, os livros atribuídos a Moisés e que são "revelação" no sentido mais estrito), seja de seus intérpretes, profetas e sábios; em último lugar, com 7 ocorrências, temos aquelas instâncias em que o uso do termo abrange um significado mais amplo ou sui generis, como acontece, por exemplo, na curiosa exortação de Jeremias $(6,8)$ "Emenda-te Jerusalém! [paideuqhsh Ierousalhm]", ou nas passagens deuteronômicas que serão discutidas mais a frente e que transmitem um sentido mais articulado de uma "educação" ou pedagogia divina, assim como, ainda, as passagens do Livro dos Provérbios (5,3 e 15,33) e do Eclesiástico (12,25; 18,13), que sugerem também, a seu próprio modo, um conceito genérico de educação. 
O primeiro exemplo, claramente discernível de uma interpretação pedagógica da ação divina na Bíblia grega, pelo menos o primeiro que eu pude verificar, se encontra no Primeiro Discurso de Moisés, no Deuteronômio, e se refere especificamente a uma estratégia de revelação. Segundo as palavras do profeta, o Deus de Israel teria falado para o povo "do meio do fogo", sem mostrar a face ou mesmo nada de si, com o objetivo de reforçar, pelo exemplo da sua aparição, o mandamento que proclamava a interdição do uso de imagens no culto que a Ele deveria ser dedicado.

Ouvíeis o som das palavras, diz Moisés, mas nenhuma forma distinguistes: nada, além de uma voz! Ele vos revelou então a Aliança que vos ordenara cumprir: as Dez Palavras, escrevendo-as em duas tábuas de pedra (...) Ficai muito atentos a vós mesmos! Uma vez que nenhuma forma vistes no dia em que o Senhor vos falou no Horeb, do meio do fogo, não vos pervertais, fazendo para vós uma imagem esculpida em forma de ídolo: uma figura de homem ou mulher, figura de alguma animal terrestre, etc. (Dt 4,12-13.15-16).

Eis um claro exemplo de uma estratégia pedagógica aplicada à revelação, ainda que a palavra paideia não seja em momento algum utilizada: o próprio modo como Deus se mostra (ou, nesse caso, não se mostra) visa passar ao povo uma lição, levá-lo, conduzi-lo, ensiná-lo o caminho da verdadeira piedade, da verdadeira adoração - sendo o preceito da Lei do Deus único clara demonstração de sabedoria (Dt 4, 6 e ss). Note-se que na passagem em tela o viés pedagógico da manifestação divina é ressaltado pelo próprio Moisés e não afirmado como um oráculo ao estilo "palavra de IHWH”, o que a meu ver indica com toda probabilidade tratar-se de uma "interpretação" do profeta, que, nesse caso, falaria a partir do seu "conhecimento" (secreto, interditado aos outros) das intenções de Deus. A meu ver, essa distinção serve para indicar que a doutrina da pedagogia divina não faz parte da revelação stricto sensu, quer dizer, como esta se dá a conhecer ao comum dos fiéis, mas antes está ligada, em sua origem, a uma gnose, uma mistagogia, algo que os escritores cristãos e, ainda na LXX, o próprio autor do livro da Sabedoria, irão sugerir ou mesmo afirmar explicitamente $^{12}$. Mas essa discussão sobre a paideia como interpretação ou

\footnotetext{
${ }^{12} \mathrm{Sb}$ 6,22. Para a representação de Moisés como mystagogos, depositário de uma sabedoria oculta que ele revela de modo cifrado e que apenas a interpretação espiritual do texto sagrado é capaz de dar a conhecer, ver GREGÓRIO DE NISSA (2000), Vita Moïse, I, 42, 46 (onde a mystagogia é colocada em estreita relação com o ensinamento que se deve tirar da Escritura), 49 (onde a lei é dita como "purificação" para uma iniciação - mystagogia - "mais perfeita", de ordem mística), 58 (onde a relação entre iniciação e pedagogia é também claramente indicada) e, finalmente, II, 201. Vale observar também que Moisés é representado ao longo de toda a obra como theleiós ou theleiotes (o subtítulo da Vida de Moisés é justamente "Tratado de Perfeição em Matéria de Virtude" ) que é ao mesmo tempo "perfeito", no sentido de paradigma de virtude, e "iniciado". Segundo Daniélou, essa caracterização de Moisés como iniciado e
} 
leitura mais sofisticada das intenções da divindade fica para depois. Agora vale mais dar seguimento ao processo de leitura das instâncias pedagógicas do texto grego. Com efeito, o segundo exemplo deuteronômico é bem mais expressivo que o primeiro, e se refere à maneira pela qual o Deus de Israel escolheu conduzir o seu povo pelo deserto e para fora do Egito, cumprindo desígnios bem específicos de salvação. Trata-se de passagens capitais do Segundo Discurso de Moisés, que têm o claro objetivo de atribuir sentido ao sofrimento do povo no caminho da busca da terra prometida. Vale a pena transcrever o trecho principal:

Observareis todos os mandamentos que hoje vos ordeno cumprir, para que vivais e vos multipliqueis, entreis e possuais a terra que o Senhor, vosso Deus, sob juramento, prometeu aos vossos pais. Lembrai-vos, porém, de todo o caminho que o Senhor vosso Deus vos fez percorrer durante quarenta anos no deserto, a fim de humilhar-vos, tentar-vos e conhecer o que tínheis no coração: iríeis observar seus mandamentos ou não? Ele vos humilhou, fez com que sentísseis fome e vos alimentou com o maná que nem vós nem vossos pais conheciam, para vos mostrar que o homem não vive apenas de pão, mas de tudo aquilo que procede da boca do Senhor. As vestes que usáveis não se envelheceram, nem vosso pé inchou durante esses quarenta anos. Portanto, reconhecei em vosso coração que o Senhor vosso Deus vos educava [Kúpıos ò $\theta \in$ cós oov $\pi \alpha \iota \delta \in \cup ́ \sigma \in \iota \quad \sigma \epsilon]$ como um homem educa seu filho, e observai os mandamentos do Senhor vosso Deus, para que andeis em seus caminhos e o temais (Dt 8, 1-6).

O trecho citado desenvolve, em praticamente toda a sua extensão, a teologia bíblica da "divina pedagogia”, que ilumina a "experiência de Israel” (ver Dt 11,1 e ss) e, por extensão, pelo menos num momento posterior, como veremos mais abaixo, da humanidade inteira. Os sofrimentos, durezas e mesmo as desgraças que na travessia o povo eleito foi forçado a enfrentar nada mais eram que provações que visavam prepará-lo para a posse da terra prometida e, principalmente, para a continuidade do verdadeiro culto e da verdadeira religião que o Deus absconditus havia revelado no deserto. Eles são, sobretudo, o penhor máximo da misericórdia divina (Deus "humilhou" e "experimentou" seu povo no deserto "a fim de fazer o bem no futuro" Dt 8,16), pois o bom pai olha com severidade os possíveis desvios do seu filho, corrigindo-o antes que por eles ele venha a se perder (Eclo 30,1 e ss).

A partir do versículo 7 Moisés deixa ainda mais claras as "razões" divinas para a imposição do duro regime de provações durante a peregrinação pelo deserto, evocando representações da natureza humana que, com efeito,

iniciador, "conhecedor dos mistérios" (mystagogos), remonta a Fílon, sendo um patrimônio genuíno do judaísmo de Alexandria (ver NISSA, 2000, p. 93 n. 1.) No que diz respeito a Gregório de Nissa ela é quase certamente uma herança de Orígenes, através de quem essas noções entraram definitivamente no pensamento cristão. 
ultrapassam largamente o contexto específico de Israel ${ }^{13}$. Segundo ele, era necessário que, no deserto, o povo passasse fome e necessidades de todo tipo, posto que a vida que o aguardava, numa terra fértil cheia de riquezas ("onde mana o leite e o mel”), o levaria facilmente à saciedade (koros), ao conforto, "elevaria” o seu coração (que para o homem bíblico era precipuamente a sede do pensamento), conduzindo-o, com isso, ao orgulho, à vaidade, à hybris e, logo, à queda, ao esquecimento de Deus (Dt 8,11-14), um tema clássico que fala da irresistível tendência humana ao amor de si e à auto-satisfação ${ }^{14}$. Sobretudo, essa condição confortável que representava o termo da longa viagem levaria o povo a esquecer aquilo mesmo que seria o mais importante lembrar - que foi Deus quem "fez sair seu povo da terra do Egito, da casa da escravidão", quem preparou e conduziu os israelitas "através daquele grande e terrível deserto, cheio de serpentes abrasadoras, escorpiões e sede" (Dt 8,16) em direção à terra prometida, de cuja abundância em breve eles iriam gozar; essa vida de felicidade terrena que o esperava, levaria enfim, o povo a esquecer que Deus é o maior bem que ele pode ter e o único com que pode realmente contar - pois os "bens" terrenos que lhes foram prometidos pela divindade, e principalmente o próprio homem cujos desejos e caprichos tornar-se-iam fatalmente objeto exclusivo de satisfação, não são sólidos nem merecedores de confiança, não sendo dignos de que, em estilo agostiniano, o povo eleito empenhe o seu "amor".

"Portanto", continua exortando Moisés, "não vás dizer no teu coração: 'Foi a minha força e o poder das minhas mãos que me proporcionaram estas riquezas'. Lembra-te do Senhor teu Deus, pois é Ele quem te concede força para te enriqueceres, mantendo a Aliança que jurou a teus pais, como hoje se vê" (Dt 8, $17-18)^{15}$.

\footnotetext{
13 Eis toda a passagem (7-16): "Contudo, fica atento a ti mesmo, para que não te esqueças do Senhor teu Deus, e não deixes de cumprir seus mandamentos, normas e estatutos que hoje te ordeno! Não aconteça que, havendo comido e estando saciado, havendo construído casas boas e habitando nelas, havendo-se multiplicado teus bois, e tuas ovelhas tendo aumentado, e multiplicando-se também tua prata e teu ouro, e tudo o que tiveres, - que o teu coração se eleve e que te esqueças do Senhor teu Deus, que te fez sair da terra do Egito, da casa da escravidão; que te conduziu através daquele grande e terrível deserto, cheio de serpentes abrasadoras, escorpiões e sede; e que, onde não havia água, pra ti fez jorrar água da mais pura pedra; que te sustentava no deserto com o maná que teus pais não conheceram, para te humilhar e te experimentar, a fim de te fazer bem no futuro".

14 Ver, a respeito, o douto estudo histórico de Marguerite Harl sobre o conceito de koros ou "saciedade" na tradição helênica (filosófica e mitológica), em HARL, 1993, p. 191 e ss. Entre as explicações que Orígenes oferece para a queda dos intelectos objeto da "primeira criação" divina se encontra justamente o koros, ou a saturação dos intelectos com a visão contínua de Deus.

$15 \mathrm{E}$ ainda: "Quando o Senhor teu Deus os tiver removido [os povos indígenas que serão expulsos da terra prometida quando da chegada do povo de Israel] da tua presença, não vás dizer no teu coração: "É por causa da minha justiça que o Senhor me fez entrar e tomar posse dessa terra”, pois é por causa da perversidade dessas nações que o Senhor irá expulsá-las da tua frente. Não! Não é por causa da tua justiça, nem pela retidão do teu coração que entrarás para tomar posse da sua terra. É por causa da perversidade dessas nações que o Senhor as expulsará da tua frente, e também para cumprir a palavra que ele jurou a teus pais, Abraão, Isaac e Jacó. Saibas, portanto: não é por causa da tua justiça que o Senhor teu Deus te concede possuir esta boa terra, pois tu és um povo de cerviz dura" (Dt 9,4-6).
} 
É principalmente nesse sentido de uma total dependência em relação a Deus, da sua radical soberania e transcendência sobre a história, característica do pensamento profético e veterotestamentário de maneira geral, que "o temor de Deus é paideia e sabedoria (phobos theou paideia kai sophia)” (Pr 15,33). E, se o temor é necessário, se, com efeito, a paideia da Providência segundo a ótica da LXX é eivada de imagens que sugerem correção, disciplina, castigo e punição, isso se dá não apenas porque o homem é visto como um ser inane, de "cerviz dura", tomado por uma tendência irresistível ao mesmo tempo para a injustiça e a auto-satisfação, mas também porque não há de fato outra educação possível entre o filho e o pai severo, ou entre o supremo soberano e o súdito que ele governa, as formas tradicionais segundo as quais o judaísmo dessa época tardia concebia as relações entre o homem (na verdade, o judeu) e o seu Deus. Sobretudo, se a sabedoria de fato reside nas alturas, em Deus (ou junto de Deus), que através dela conhece, sozinho, todas as criaturas e seus caminhos, se ela não é um princípio à disposição de quem queira procurá-la, nem tampouco algo simplesmente inato no homem (pelo menos não enquanto sabedoria), mas a expressão do cuidado e da misericórdia do Deus criador e redentor, e se, por isso mesmo, ela não pode ser representada de outro modo senão como uma concessão, um dom mais ou menos gratuito, então, neste contexto, as imagens a princípio exacerbadamente heteronômicas usadas para sugerir a sua maneira de educar (a maneira com que Ele exerce a sua ascendência sobre o homem) adquirem todo o seu sentido.

\section{A PAIDEIA NA LITERATURA SAPIENCIAL DO JUDAÍSMO ALEXANDRINO}

No sentido antropológico, o que se faz presente nesta ação divina que educa pela dureza e pela provação é aquela "passividade" inerente ao objeto da paideia providencial a que aludimos mais acima. Para o grego, sábio é aquele que adquire a sabedoria, que a toma para si, que atinge a perfeição possível ao homem apenas através do próprio esforço e autodisciplina; para o judeu, mais especificamente para a literatura sapiencial que conheceu o seu florescimento no judaísmo tardio, sábio é aquele que se deixa instruir ( $\delta\llcorner\delta \alpha \chi \theta \epsilon \nu \tau \epsilon \varsigma-\mathrm{Sb} 6,10)$, aquele que, temendo o Senhor, aceita a correção - a paideia (Eclo 32,14) - vinda do alto, pois a todo tempo - e isso é o que, em definitivo, é preciso considerar - a iniciativa educativa (que deve levar à salvação) não é do homem ou da natureza, mas de Deus. Assim, encontrar a sabedoria é curvar-se ao jugo, à disciplina, é aceitar o castigo, sofrer um tratamento intensivo de redirecionamento da 
cerviz $^{16}$, e o Deus que educa é como o pastor que eventualmente se vê na contingência de descer o cajado na sua ovelha para que ela não venha a extraviar-se, uma imagem bastante expressiva das representações tipicamente judaicas a respeito da soberania de Deus e sua "paternidade" em relação ao homem. ${ }^{17}$

No Livro da Sabedoria, Salomão, o paradigma do sábio para o judeu antigo, diz textualmente que, tendo-a amado e buscado a vida inteira, logo compreendeu que só acharia a sabedoria se ela lhe fosse concedida pelo próprio Deus. Diante disso, nada mais natural para alcançá-la do que lançar-se numa oração de súplica, algo que um grego, como Sócrates, por exemplo, não poderia fazer sem ironia.

Ao me dar conta de que somente a ganharia [a sabedoria]

Se Deus ma concedesse

- e já era sinal de entendimento saber a origem desse favor -

Dirigi-me ao Senhor e rezei... (Sb 8,21)

Nesse mesmo sentido aponta o adágio de Jesus Ben Sirá (Eclo 43,33): "aos homens piedosos Ele dá a sabedoria”, de modo que aquilo que a gregos e judeus igualmente se afigura como a perfeição do ser humano, é representado, em sua essência, como um favor concedido pela divina misericórdia ${ }^{18}$, assim como o é igualmente a paideia que o produz e que, a contar pelos relatos bíblicos que estamos perquirindo, se apresenta como de tão difícil digestão. Pois, como evidencia a passagem do Deuteronômio recém discutida, Israel só foi educado com a privação e os terríveis sofrimentos do deserto porque era o povo eleito de Deus, que só educa a quem ama ${ }^{19}$. Com efeito, Paulo traduz com perfeição essa doutrina capital do judaísmo bíblico quando diz que é preciso alegrar-se com a tristeza que vem de Deus, pois ela produz o arrependimento (metanoia) que leva à reforma do coração (2Cor 7,8 e ss). Em termos essenciais, a educação do Espírito Santo - literalmente "o espírito santo da paideia” (hagion pneuma paideias) - de que fala o prólogo do livro da Sabedoria ( $\mathrm{Sb}$ 1,5), é representada exatamente dessa forma, como um convite divino ao arrependimento e à conversão (epístrophe), duas palavras que, em grego, indicam sobretudo uma reviravolta, um reviramento, uma mudança de curso, direcionamento ou

\footnotetext{
16 "Escuta, filho, e aceita meu parecer, não rejeites meu conselho; mete teus pés nos seus grilhões [da paideia de sabedoria] e teu pescoço no seu jugo. Abaixa o teu ombro e carrega-a e não te irrites com seus liames" (Eclo 6, 23-25). Ver também a violenta exortação à sabedoria com que Sirá fecha o livro: "Colocai vosso pescoço sob o jugo, recebam vossas almas a instrução [paideia]” Eclo 51,26.

17 Um dos termos da Bíblia hebraica traduzidos por paideia é lamad, "ensinamento", que de modo muito característico significa também “cajado".

${ }^{18}$ A mesma ideia se encontra de maneira explícita em Eclo, 51,29.

${ }^{19} \mathrm{Hb} 12,6$.
} 
sentido no modo de vida ou na conduta - na postura ou mesmo na "forma" da alma em si.

Nesse espírito, todo o esquema e a intencionalidade da educação divina na Bíblia Grega encontram-se resumidos em algumas poucas passagens da Sabedoria de Ben Sirá (o nosso “Eclesiástico”):

Pois, primeiro, caminhará com ele em sentido inteiramente contrário (diestrammenōs) ${ }^{20}$

E lhe incutirá temor e tremor,

E o provará com a sua disciplina [paideia]até que confie nela

E ela o teste com as suas exigências.

Depois, voltará a ele em linha reta, o alegrará

E lhe desvendará seus segredos.

Se ele se desviar, ela o abandonará

E o entregará às mãos da própria ruína (Eclo 4,17-19).

Assim, Deus, em sua misericórdia,

Admoesta [elenchon], corrige [paideuon], ensina [didaskon],

Reconduz [epistrephon], como o pastor, o seu rebanho.

Ele tem piedade dos que recebem a disciplina [paideia]

E se apressam a procurar seus julgamentos (Eclo 18, 13-14).

E ainda:

Pouco a pouco corriges [elencheis] os que caem,

E os admoestas, lembrando-lhes as faltas,

Para que, tendo-se afastado do mal, creiam em ti, Senhor (Sb 12,2).

Todo o arsenal de imagens que delimitam os contornos da paideia bíblica alexandrina encontra-se exemplificado nessas poucas passagens. Primeiro a iniciativa divina e a consequente subordinação do homem, as características que indicam o "temor e tremor" sobre os quais se estrutura a relação ontologicamente dessemelhante entre criador e criatura e que nunca é demais sublinhar. É, com efeito, notável que praticamente todos os verbos de conteúdo propriamente educativo (admoestar, corrigir, ensinar) tenham Deus, sua Sabedoria, sua Providência ou sua misericórdia como sujeitos, uma vez que o homem, esse ser de “espírito emprestado", padece de uma total inanidade ontológica, incapaz que é de, por si mesmo, comunicar a vida a qualquer de suas criações ${ }^{21}$.

${ }^{20} \mathrm{O}$ sujeito do discurso é a "sabedoria educadora".

${ }^{21}$ A fragilidade do homem é afirmada no contexto da condenação à idolatria (uma tendência sempre constante do ser humano segundo toda a antropologia do Antigo Testamento) ao longo do capítulo 15 do Livro da Sabedoria, de um modo que dificilmente será igualado pela tradição posterior. Ali o homem é acusado de buscar modelar uma "divindade vazia" a partir da argila de que ele próprio é feito, logo ele que, 
Depois há a profusão de imagens que indicam caminho, direção, passagem, rota, que sugerem a maneira pela qual Deus alternativamente "corrige", "leva" ou "reconduz" o ignorante [apaideutos], insensato, ímpio ou pecador (todos estes termos são utilizados em estrita sinonímia pelo autor bíblico), e que apontam para o significado eminentemente ético da educação divina na ótica judaica ${ }^{22}$. Segundo o que parece ser a intenção original da LXX, a sabedoria (i.e., a perfeição) a que essa educação promete conduzir não se refere, pelo menos não primordialmente, ao conhecimento de algo ou à revelação de doutrinas secretas acerca de Deus (uma concepção que mudará de maneira sensível com Clemente e Orígenes e o seu ideal de uma gnose cristã ${ }^{23}$ ), mas essencialmente à consecução de uma vida santa, entendida como uma adesão cada vez mais total aos caminhos e à lei divinos que sozinhos levam à imortalidade. Por isso o curioso é advertido de que a sua curiosidade é vã e que, antes de muito perguntar, é necessário confiar na Providência:

Não é preciso dizer: "O que é isto? Por que aquilo?"

Porque tudo foi criado para uma destinação (Eclo 39,21).

E o homem, mais uma vez lembrado da sua profunda inanição, deve ter sempre como centro e alvo da sua busca por sabedoria o temor de Deus:

Pois, que homem conhece o desígnio de Deus?

Quem pode conceber o que deseja o Senhor?

Os pensamentos dos mortais são tímidos

E falíveis nossos raciocínios;

Um corpo corruptível pesa sobre a alma

E esta tenda de argila faz o espírito

Pesar com muitas preocupações.

A custo conjecturamos o terrestre,

Com trabalho encontramos o que está à mão:

\footnotetext{
"desconhecendo Aquele que o modelou (...) pouco antes nascera da terra e em breve voltará à terra de onde foi tirado, quando se lhe pedirá conta da vida [ psychē] que lhe foi emprestada”. Vale notar que toda esta violenta denúncia das pretensões usurpadoras do homem em relação à soberania divina, na verdade mais típica do discurso profético que da própria literatura sapiencial, é feita, segundo o autor do livro, em nome de algo como um autêntico humanismo (ou philantropia): "nenhum homem pode plasmar um deus semelhante a si; mortal, suas mãos ímpias produzem um cadáver. Ele é melhor do que os objetos que adora: ele pelo menos teve vida, eles jamais!” (15,8.11.16-17 - grifos meus)

${ }^{22}$ Aqui cumpre observar que não é, em absoluto, a sua natureza eminentemente ética o que distingue a sabedoria bíblica da sabedoria filosófica; esta última, como demonstraram a meu ver de modo definitivo, entre outros, Werner Jaeger e Pierre Hadot, também é, em última análise, de natureza ética, uma vez que tem como fim último a concretização de um modo de vida, a bios theoretike entendida como a vida feliz. Cf. JAEGER, 1995, p. 423 (sobre a vida de Sócrates como paradigma do filósofo) e Banquete 211D: "Uma vida como essa, diz a sacerdotisa Diotima a Sócrates, vivida na contemplação do belo, é a vida que para o homem vale a pena ser vivida [bios ou biotós antropo]". Sobre esta problemática ver também LEOPOLDO E SILVA, 2004: pp. 35-49.

$23 \mathrm{E}$ que, não obstante, já começa a mudar a partir dessa própria literatura sapiencial, que fala, por exemplo, da Sabedoria divina como detentora dos segredos da criação do mundo ou do destino do homem após a morte, um conhecimento "secreto" que ela dispensa a quem quer, normalmente (aí é que está) ao homem piedoso cumpridor da lei.
} 
Mas quem rastreará o que está nos céus?

Quem conhecerá tua vontade se não lhe deste sabedoria

E não enviaste do Alto o teu espírito Santo?

Somente assim foram retos os caminhos dos terrestres,

E os homens aprenderam o que te agrada,

E a sabedoria os salvou" (Sb 9, 13-18)

E, ainda:

Conhecer-te é a justiça integral,

E reconhecer a tua soberania é a raiz da imortalidade (Sb 15,3) 24.

Por último, evidencia-se naquelas passagens do Eclesiástico que viemos discutindo o telos e o sentido maior, salvífico, da educação dispensada, que visa ao arrependimento e à conversão (metanoia, epistrophe), expressos por um vocabulário de metáforas de intenso valor religioso tiradas daquelas mesmas imagens tantas vezes reiteradas indicativas de movimento, retorno, mudança de direção, um conjunto de representações que fará fortuna na teologia posterior, particularmente a partir do Evangelho. Com efeito, antes da literatura sapiencial nascida no ambiente do judaísmo alexandrino parecia não haver muita clareza acerca da finalidade da educação divina na história; ou, quando clareza havia, tratava-se de uma finalidade sobremaneira restrita, em termos teológicos insatisfatória em sua elaboração. Nos relatos mais antigos, como no exemplo deuteronômico estudado mais atrás (poder-se-ia citar muitos outros), ela parecia restringir-se à salvação (no sentido de um resgate histórico) do povo eleito ou à perseverança na fidelidade ao Deus único prometida na Aliança do Sinai, da mesma forma que a sabedoria era equiparada ao simples cumprimento da lei revelada, algo que, aliás, se manteve como uma de suas definições mais frequentes mesmo em períodos bem posteriores da religião judaica ${ }^{25}$. Nenhuma referência se fazia, por exemplo, ao destino espiritual do homem enquanto homem, ou a um desígnio de Deus para com a humanidade considerada de uma maneira geral, para além do povo eleito. Mesmo em algumas passagens da literatura sapiencial mais recente (composta em sua maior parte entre os séculos IV e I a. C.), onde a mistura de doutrinas de épocas diversas é perpassada pela influência do universalismo alexandrino, percebe-se, aqui e ali, a presença do espírito deuteronômico marcado pela exclusividade da eleição. É o que acontece, por exemplo, no Eclesiástico, onde Israel é chamado de "a porção do Senhor, seu primogênito que ele alimenta de paideia” (Eclo 17, 17-18), uma passagem que

24 Por isso o temor de Deus é representado não apenas como o "início" da sabedoria, mas como o caminho que conduz a ela (a sua paideia), e ainda a sua "coroa", "plenitude" e perfeição (ver Eclo 1, 14.16.18). Em última instância o phobos tou kyriou tantas vezes repetido se confunde com o caminho do amor: "O temor do Senhor é dom que vem do Senhor; com efeito, ele o estabeleceu sobre os caminhos do amor" (Eclo 1,12)

${ }^{25}$ Cf. Eclo 19,20 
deve ser lida em paralelo com outro conjunto de textos da Sabedoria de Salomão, que fala de duas atitudes pedagógicas diferentes, uma severa, para com os egípcios, e outra, mais branda, aplicada à Israel ${ }^{26}$.

Não obstante isso, e em contraste com a teologia anterior, essas mesmas passagens sublinham, lado a lado com certo tratamento privilegiado dado ao povo eleito, a intenção pedagógica de Deus também para com aqueles que se recusavam a reconhecê-lo (seus "inimigos"), estendendo com isso a educação divina a todos que são objeto de castigo de maneira geral, uma universalização do cuidado providencial para com os homens que o texto relaciona claramente à percepção de Deus como criador.

Sim, tu amas tudo o que criaste,

Não te aborreces com nada do que fizeste.

Se alguma coisa tivesses odiado, não a terias feito.

E como poderia subsistir alguma coisa,

Se não a tivesses querido?

Como conservaria sua existência, se não a tivesses chamado?

Mas a todos poupas, porque são teus:

Senhor, amigo da vida 27 !

Todos carregam o teu espírito incorruptível (Sb 11,24-12,1) ${ }^{28}$.

Segundo a "nova" teologia expressa nestes poucos versos é por conta desse amor universal, dessa philanthrōpia (ou philopsiquia), que, animado de intenção pedagógica, o Senhor tratou os inimigos do seu povo, nesse caso os cananeus, com "medida", "clemência” ou "moderação" 29 :

Mas mesmo a eles, homens que eram,

Tu os trataste com indulgência,

Mandando-lhes vespas como precursoras do teu exército,

Para exterminá-los pouco a pouco ${ }^{30}$.

\footnotetext{
${ }^{26}$ Refiro-me às "antíteses" que falam da diferença de tratamento dispensado aos egípcios (as pragas) e ao povo de Deus (que era mais bem submetido a uma série de "sustos"; ver Sb caps. 16-18) Numa delas, a primeira, o autor diz que os israelitas foram submetidos a provações "que não eram senão correções de misericórdia” enquanto os ímpios foram sentenciados com cólera ( $\mathrm{Sb}$ 11,9).

27 Lit: "amigo das almas" [philopsichai].

${ }^{28}$ Ver também Eclo 39,33-35

29 Para o uso da palavra "moderação" [epieikéia], ver Sb 12,18.

${ }^{30}$ En passant cumpre apontar para o fato de que o autor introduz, talvez pela primeira vez na Bíblia, a questão do "prazo" da justiça divina a propósito do episódio das "vespas" responsáveis pela exterminação dos cananeus, justificando-a, para nós muito significativamente, de um lado pela universalidade da misericórdia divina, e de outro por sua intenção pedagógica para com os cananeus, duas questões que os textos mais antigos (Ex 23,28; Dt 7,20) sequer consideravam. O exame destes textos é interessante na medida em que deixa ver com maior clareza em que consiste realmente uma interpretação pedagógica da ação providencial. Ali, tanto no Êxodo quanto no Deuteronômio (que nesse caso lhe é provavelmente tributário), a "demora" na conquista da terra prometida é explicada basicamente em termos utilitários, como uma maneira de domesticar ou expulsar as feras dos campos que vicejavam por ali, e que de outro modo, sem a presença das outras nações, se multiplicariam e terminariam por devorar o povo eleito. Cf. a nota $f$ à p. 1124 da "BJ" (2002).
} 
Bem que podias ter entregue os ímpios às mãos dos justos numa batalha,

Ou tê-los aniquilado de uma só vez,

Com animais ferozes ou uma palavra inexorável;

Mas, exercendo os teus julgamentos,

Dava-lhes ocasião de conversão [metanoias],

Muito embora não ignorasses que fossem de má origem,

De malícia congênita,

E que a sua mentalidade não mudaria jamais (Sb 12-8-11). $3^{1}$

Uma concepção análoga se faz presente na afirmação de um "castigo progressivo" que teria sido infligido aos egípcios ( $\mathrm{Sb}$ 12,23 e ss) como uma estratégia da divina Sabedoria mais uma vez concebida para propiciar ao pecador a possibilidade de conversão, de "retorno" a Deus ${ }^{32}$, e que, no caso em tela, ter-se-ia concretizado ao modo de uma série de advertências e "repreensões salutares" (Pr 15,31), entendidas como sucessivos chamados à conversão. Foi somente por causa da sua obstinada persistência no pecado, análoga ao célebre "coração duro" de seu líder, o Faraó, que os egípcios tiveram que enfrentar a "última condenação" (13,27), a morte coletiva por afogamento no Mar Vermelho33. Aqui, o que mais importa é observar que essa nova concepção teológica representa o termo de uma longa evolução da religião judaica em direção à universalidade, com o resultado de que a intenção educativa da ação da Providência deixa de ser apanágio do povo eleito, estendendo-se igualmente para toda a humanidade ("mesmo a eles, homens que eram"). Pois se o homem, nos diz um inspirado Jesus Ben Sirá, só se preocupa (se tanto) com o seu próximo, "a misericórdia de Deus derrama-se sobre toda carne” (Eclo 18,13).

\footnotetext{
${ }^{31} \mathrm{E}$ ainda: "Assim procedendo, ensinaste a teu povo que o justo deve ser amigo dos homens [philantropos como o é o próprio espírito de sabedoria $(1,6 ; 7,23)$, o Espírito Santo da Educação mencionado no prólogo], e a teus filhos deste a esperança de que, após o pecado, dás a conversão [metanoia]. Pois se os inimigos de teus filhos, réus de morte, com tanta atenção e indulgência castigaste, dando-lhes lugar e tempo para se afastarem de sua malícia, com que precaução julgaste os teus filhos, a cujos pais, com juramentos e alianças, tão belas promessas fizeste? Assim, nos instruis [paideuon] quando castigas nossos inimigos com medida, para que, ao julgar, nos lembremos da tua bondade e, ao sermos julgados, contemos com a tua misericórdia" (Sb 12, 19-22). Nota-se, aqui, um outro aspecto daquela dupla dimensão que o conceito de paideia vai sempre ter no contexto da religião revelada e que será discutido no fechamento do presente ensaio: a importância do exemplo, do castigo ou correção reconhecido na vida dos outros.

32 É interessante observar que o autor do Livro da Sabedoria parece esposar a teoria de que no início era o monoteísmo, tendo o culto a uma diversidade de deuses aparecido como uma corrupção desse estado original, ao qual o pagão convertido não faria mais do que voltar. Cf. Sb 14,13-14 e n. a BJ p. 1129. Para uma melhor especificação do significado religioso de epistrophe na LXX, ver Eclo 17,26: Volta para o Altíssimo, desvia-te da injustiça [apostrephe adikias], pois é ele que te guiará das trevas à iluminação da salvação.

33 Sobre a representação da obstinação dos egípcios como causa da sua desgraça coletiva aos olhos de Deus, é curioso observar que o autor do Livro da Sabedoria parece endossar, como o fará seu compatriota Orígenes, uma teoria avant la lettre da predestinação por previsão de méritos, como atesta a passagem a seguir: "Mas sobre os ímpios abateu-se até o fim uma cólera implacável, porque Ele sabia de antemão o que iriam fazer: que os deixariam partir e urgiriam para que se fossem, mas logo, mudando de parecer, os perseguiriam" (19,1-2 - grifo meu)
} 
Em nenhum lugar essa nova universalidade alcançada pelo judaísmo se deixa ver com maior evidência do que na afirmação, inédita, pelo menos nos termos em que é proposta, do fim sobrenatural de todo homem enquanto criação divina, uma imagem da vida humana e seu significado na qual se insinua claramente uma perspectiva escatológica que determina o alcance e os termos precisos - o que os gregos chamavam de skopos do processo da divina educação:

Deus criou o homem para a incorruptibilidade

E o fez imagem da sua própria natureza $(2,23)$.

Imagem divina, para o autor do Livro da Sabedoria o destino do homem é ser eterno como o seu modelo, e a sua educação deve atender às exigências contidas nesta identificação. Sob esse prisma, a ação de Deus não visa mais à conquista de um pedaço de terra, ainda que santo, ou ao resgate de um povo, ainda que seja a humanidade inteira, da casa da escravidão; sua finalidade é preparar o homem enquanto homem para aquilo que o espera depois da morte, cuidar da sua alma, purificá-la, para que, finda a vida, ela possa sobreviver, o que se coloca também como o objetivo último de uma vida perfeita, levada segundo os ditames da mais alta sabedoria. Essa dimensão propriamente escatológica da paideia providencial, que lhe atribui todo outro conjunto de significados, se insinua de modo particular nos desenvolvimentos relativos ao destino dos justos representado em contraposição ao dos ímpios, uma questão que o Livro de Jó em particular, e, de resto, praticamente todo o corpo da revelação, encontrava muita dificuldade em responder. Para o autor do Livro da Sabedoria a questão deve ser remetida à dimensão da imortalidade, o que significa postular, pela primeira vez na tradição teológica, de modo tímido, é verdade, a possibilidade de uma retribuição pela vida vivida no tempo no plano do sobrenatural.

A vida dos justos está nas mãos de Deus,

Nenhum tormento os atingirá.

Aos olhos dos insensatos pareceram mortos;

Sua partida foi tida como uma desgraça,

Sua viagem para longe de nós como um aniquilamento,

Mas eles estão em paz $(3,3)$.

Com a assunção da noção de uma vida após morte afirma-se a ideia, fundamental para o pensamento religioso posterior, de uma educação para a imortalidade, de um processo de formação do homem que, dando-se como todos os outros aqui na terra, no seio da existência concreta, deve render seus frutos apenas numa outra vida, interditada aos olhos carnais. Esta perspectiva opera, em relação às ideias de sucesso e fracasso, de bênção e maldição 
tradicionais no judaísmo anterior, uma completa inversão. O que na terra se vê como desgraça e infelicidade deve doravante ser visto na verdade como a intimidade constante de uma vida com Deus (o justo é "visitado" por Ele em seu sofrimento - Sb 3,7), e aquilo que parecia numa vida de prazeres e prosperidade material representar a plena realização de todas as possibilidades humanas, torna-se o aniquilamento, uma sentença inescapável de destruição. Como exemplo do que fizeram antes dele os profetas ao lançar-se a ver todas as coisas "do ponto de vista divino" - uma perspectiva que, em relação ao mundo, traduzse essencialmente como julgamento -, o Salomão do Livro da Sabedoria entendeu que se deve interpretar a vida (e este julgamento) do ponto de vista da alma e a vida da alma a partir de seu destino eterno, em Deus.

De fato, tendo o Deus bíblico como fiador esse destino significa na verdade algo bem diverso daquele que se encontra magistralmente representado na escatologia do Fedro ou no mito de Er; ali, enquanto Platão lança mão de uma elaborada narrativa mitológica como um artifício para ilustrar a vida presente e os valores que devem corresponder a ela (a "escolha de vida" - bion airesis que segundo Sócrates resume a tarefa do homem ${ }^{34}$ ), no ambiente da revelação judaica dá-se exatamente o contrário: é a representação do destino último que deve determinar a vida nesta terra, ou, mais propriamente, o determinante é a natureza divina desse destino, orientando todas as coisas, e inclusive a sabedoria, numa outra direção.

Aos olhos humanos pareciam cumprir uma pena,

Mas sua esperança estava cheia de imortalidade ${ }^{35}$;

Por um pequeno castigo receberão grandes favores.

Deus os submeteu à prova

E os achou dignos de si.

Examinou-os como o ouro no crisol

E aceitou-os como perfeito holocausto.

No tempo de sua visita resplandecerão

E correrão como fagulhas no meio da palha ( $\mathrm{Sb} 3,4-7)$

Por isso torna-se possível exclamar com o salmista: "Feliz o homem a quem corriges [paideuses], Senhor" (Sl 93,12), pois a ele é dada a opção do caminho da imortalidade. No que diz respeito ao justo, os males que se percebe acontecer a ele devem ser interpretados, ao contrário do que pensa o senso comum (a "multidão"- cf. Sb4,14), como "intervenções salutares", na medida em que

34 Ver JAEGER, 1995: p. 539.

35 Athanasia, segundo o editor da Bíblia de Jerusalém (BJ 2000), em sua primeira aparição em todo o Antigo Testamento. Ver n. $j$ p. 1108. Exceções devem ser feitas às menções à imortalidade como vida após a morte presentes no apócrifo 4Mc 14,5; 16,13. 
indicam o cuidado de Deus para com ele, significando uma oportunidade de mudança, de correção de rumo, uma passagem dos seus próprios caminhos para os caminhos que levam à felicidade eterna, na qual os ímpios, com a sua arrogância, jamais serão capazes de entrar ${ }^{36}$. Estes últimos, ainda que procurados como todos os outros pelo cuidado divino universal e chamados à conversão, excluem-se a si mesmos da dupla recompensa da sabedoria e da vida eterna por não reconhecerem a importância de submeter-se à educação que sozinha deve levar a elas (não raro sequer reconhecendo a existência dessa educação) .

Desgraçados os que desprezam a sabedoria

e a disciplina [sophian kai paideian]:

Sua esperança é vã,

Suas fadigas sem proveito,

Suas mulheres insensatas,

Seus filhos depravados,

Sua posteridade maldita! (3,11-12).

Sim, a esperança do ímpio é como palha levada pelo vento,

Como a espuma miúda que a tempestade espalha;

É dispersa como fumo pelo vento,

Fugaz como a lembrança do hóspede de um dia $(5,14)$

Quando tiverem de prestar contas de seus pecados

Virão cheios de terror

E seus delitos os acusarão frontalmente $(4,20)$

Senhores de si, (“cegos" pela própria maldade, diz o texto [2,21] e enganados por "falsos raciocínios"), e tendo obstinadamente se recusado à penitência e ao arrependimento, eles serão chamados a julgamento e passarão na vida como uma sombra. Achando-se sábios, privam-se do único acesso possível aos "segredos de Deus" (que consiste na sua "disciplina”); e, não crendo na existência de uma recompensa para as almas puras $(2,22)$, condenam-se à perdição. Dentre todos, diz o autor do livro, este último é o maior erro que o ímpio comete. E, de fato, percebe-se pela descrição da "vida segundo os ímpios" desenvolvida ao longo do segundo capítulo da Sabedoria de Salomão exatamente o que, com isso, o autor está querendo dizer: materialismo37,

\footnotetext{
${ }^{36}$ A despeito do esquematismo da apresentação, não se deve pensar que o autor do Livro da Sabedoria simplesmente exclui do horizonte dos justos, à maneira, digamos, de um Santo Agostinho, a perspectiva de recompensas nesta mesma vida, o que já seria contrariar demais a tonalidade própria da mentalidade judaica do seu tempo. Não obstante, abundam no texto as instâncias críticas ou pelo menos reformadoras em relação ao ideal tradicional de felicidade. Cf. p. ex., a relativização da "bênção" de uma extensa posteridade em 3,13 e ss ou mesmo da ideia da morte como castigo em 4,7 e ss. As duas noções encontramse misturadas no cap. 16 do Eclesiástico, que antecede a Sabedoria de Salomão em provavelmente dois séculos.

37 "Fumaça é o sopro do nosso nariz, e o pensamento, centelha do coração que bate. Extinta ela, o corpo se tornará cinza, e o espírito se dispersará como o ar inconsistente” (2,2-3)
} 
relativismo ${ }^{38}$, pessimismo existencial 39 , afirmação do acaso ${ }^{40}$, hedonismo ${ }^{41}$, são todas características do "ímpio" que, através delas, pode ser mais bem definido como alguém que nega a existência de uma educação divina, de um governo moral do mundo por uma vontade transcendente ou, no limite, a existência mesma de uma Providência, constituindo-se assim numa figura arquetípica de homem não religioso que a tradição judaica viria a nomear, por antonomásia, de epicurista ${ }^{42}$, e cujo ideal de vida consistia no que se pode chamar de "ateísmo prático" - alguém que pensa, vive e age como se não houvesse Deus, como se as ideias e a sensibilidade do homem, em sua existência terrena, fossem as únicas medidas da justiça.

O lema deste grupo de alegres e desgraçados indivíduos descrito em cores expressivas pelo Salomão alexandrino poderia ser o mesmo do famoso personagem de Dostoievski: se Deus não existe, tudo é permitido43. Em todo caso, para nós o que interessa é perceber como a sua falta primeira, aquela que está na raiz de todo o perigo, mal e estultícia que eles representam, é recusar o jugo da educação divina, manter a cerviz dura, não deixar-se instruir, negar-se a ser reconduzidos, a "dar a volta”, não ouvir o chamado para o arrependimento e a conversão. Algo que antes de tudo nos leva a pensar que para o autor bíblico, assim como para uma boa parte da tradição teológica fundada nos princípios que ele estabeleceu ou simplesmente adotou de outras fontes, tão importante quanto a pedagogia e a justiça divinas propriamente ditas é reconhecer (ou ser levado a reconhecer) que essa pedagogia e essa justiça existem, na medida em que este reconhecimento, eminentemente útil, é capaz de impor uma certa ordem ao caos empírico do comportamento humano e à sua tendência para a

\footnotetext{
38 "Cerquemos o justo porque nos incomoda (...) Declara ter o conhecimento de Deus e se diz filho do Senhor (...) Proclama feliz o destino dos justos e se gloria de ter a Deus por pai; vejamos se suas palavras são verdadeiras, experimentemos o que será do seu fim” (2,12.13.16-17).

39 "Breve e triste é nossa vida, dizem os ímpios, o remédio está no fim do homem, não se conhece quem tenha voltado do Hades" $(2,1)$ "Com o tempo nosso nome cairá no esquecimento e ninguém se lembrará de nossas obras; nossa vida passará com uma nuvem - sem traços -, se dissipará como a neblina expulsa pelos raios de sol e, por seu calor, abatida. Nossa vida é a passagem de uma sombra, e nosso fim, irreversível; o selo lhe é aposto, não há retorno" $(2,4-5)$.

40 "Nós nascemos do acaso e logo passaremos como o que não existiu" $(2,2)$

41 "Vinde, pois, desfrutar dos bens presentes e gozar das criaturas com ânsia juvenil. Inebriemo-nos com o melhor vinho e com perfumes, não deixemos passar a flor da primavera; coroemo-nos com botões de rosas, antes que feneçam; nenhum prado ficará sem provar da nossa orgia, deixemos em toda parte sinais de alegria pois esta é a nossa parte e nossa porção" (2,6-9) Esta descrição do pessimismo e ao mesmo tempo hedonismo dos ímpios aproxima-se de modo perturbador do carpe diem incensado (supostamente pelo mesmo Salomão) no Qohelet.

42 Ver STRAUSS, 1997.

43 “Oprimamos o justo pobre, dizem eles, não poupemos a viúva, nem respeitemos as velhas cãs do ancião. Que nossa força seja a lei da justiça, pois o fraco, com certeza, é inútil. Cerquemos o justo, porque nos incomoda e se opõe às nossas ações, nos censura as faltas contra a Lei, nos acusa de faltas contra a nossa educação [paideia]" (Sb 2,10-12)
} 
injustiça e o mal, estabelecendo a perspectiva de um governo moral, concreto do mundo diretamente referido ao sobrenatural.

\section{CONCLUSÃO}

Os textos sugerem que a correção divina aproveita ao pecador somente, e apenas somente quando este tem consciência de que está sendo objeto dela e procura se emendar ("aceitando a instrução"); na realidade, o simples reconhecimento de que o homem é objeto de uma estratégia educativa da parte de Deus é proveitoso em si mesmo, quer dizer, para todos os que queiram apropriar-se dele, inclusive pelo exemplo alheio, como é o caso do castigo progressivo dos egípcios e da invasão das vespas ao território cananeu, pragas exemplares que só adquirem a sua significação plena quando aplicadas pelos Israelitas na emendatio dos seus próprios caminhos (uma vez que as suas vítimas, obstinadamente em apaideusia, estão condenadas desde o princípio a nada "aprender com elas"). Desse modo, torna-se evidente que tão importante quanto sofrer a ação divina, é reconhecê-la e atribuir a ela o sentido apropriado que sozinho levará ao sucesso da estratégia educativa, em nome da qual a própria ação foi concebida em primeiro lugar. Se este reconhecimento é, em si mesmo, declarado um dom divino (ele é a própria "sabedoria”), ele não elimina a importância fundamental, que a todo o momento é afirmada pelo autor bíblico, de uma educação da educação, quer dizer, de uma "educação religiosa" que leve a ele no plano concreto do mundo e da ação humana, uma ordem humanamente construída a partir da incorporação das lições de Deus. Isto significa além de tudo o que foi dito, que a pedagogia divina só rende todos os seus frutos quando é entendida não como "teologia", isto é, como "interpretação" humana do significado da fala e da ação da divindade, mas como autêntica "revelação", com autoridade para corrigir, para guiar, para formar.

Enfim, ao sugerir a existência de castigos e recompensas na outra vida parece ser exatamente essa a intenção do autor do Livro da Sabedoria. O que me parece sugerido principalmente pelo zelo com que, maldizendo os ímpios, ele alardeia a sua ignorância e falta de instrução. Com efeito, de que adiantaria no que diz respeito à sua eficácia no mundo concreto, haver um governo divino das coisas humanas se o próprio homem dele não soubesse ou não o quisesse reconhecer? É forçoso, portanto, que a pedagogia divina se desvele sempre nessa dupla dimensão: a ação de Deus e o discurso correto, eficaz no que toca à correção dos caminhos, a respeito dessa mesma ação. 
Erraria por muito, entretanto, quem achasse que esta "necessidade" de se fazer reconhecida para multiplicar seus efeitos benéficos no mundo faz da doutrina da educação divina apenas uma mentira piedosa (ainda que uma "nobre mentira"), contada e encenada exclusivamente em nome da utilidade "social". O fato é que discutir a verdade ou falsidade dessa doutrina que não teria qualquer relevância para a presente discussão: justamente porque a necessidade de reconhecimento que determina a sua eficácia plena faz parte da própria dinâmica do conceito de paideia, que, como foi sugerido quando começamos a falar da articulação dessa doutrina na Bíblia grega, desde a sua incorporação à religião revelada opera sempre nessa dupla dimensão - uma dimensão teológica propriamente dita, que viemos desenvolvendo até aqui, e uma dimensão que poderíamos chamar, na falta de melhor palavra, "social” ou "ética", pertinente à orientação concreta da vida (refletida nas instituições educativas e seus instrumentos), baseada nos princípios da primeira, e que de modo geral se entende como parte indispensável de um único e mesmo processo de educação, cuja origem é, não obstante, afirmada como sobrenatural.

\section{REFERÊNCIAS}

Agostinho, Santo. A cidade de Deus. 7. ed. Petrópolis: Vozes, 2002. v. 2.

BÍBLIA. A Bíblia de Jerusalém. São Paulo: Paulus, 2002.

BRENTON, Lancelot Charles Lee Sr. The Septuagint version of the Old

Testament and Apocripha: with an English translation and various readings and critical notes. London: Samuel Bagster, 1900.

Vetus Testamentum Graecum: Auctoritate Academiae Scientiarum Gottingensis editum, 67 vols. Göttingen: Vandenhoeck \& Ruprecht, 1931-2006.

DICIONÁRIO Patrístico e de Antiguidades Cristãs. Petrópolis: Vozes, 2002.

DORIVAL, Gilles. HARL, Marguerite (Ed.). La Bible d'Alexandrie LXX. Paris : Éditions du Cerf, 1981- .

DORIVAL, Gilles. HARL, Marguerite (Ed.). La Bible grecque des septante: du judaïsme hellénistique au christianisme ancien. Paris: Éditions du Cerf, 1994.

HARL, Marguerite. Le déchiffrement du sens: études sur l'herméneutique chrétienne d'origène à Grégoire de Nysse. Paris: Institut d'études Augustiniennes, 1993.

IGREJA CATÓLICA. Nova Vulgata: Bibliorum Sacrorum Editio. Vaticano, Disponível em: <http://www. vatican.va/archive/bible/nova_vulgata/documents/nova vulgata_Index_it.html > 
JAEGER, Werner. Cristianismo primitivo e paidéia grega. México: Fondo de Cultura Económica, 1995.

JAEGER, Werner. Paideia: los ideales de la cultura griega. México: Fondo de Cultura Económica, 1998.

LOUTH, Andrew. The origins of the christian mystical tradition. New York: Clarendon Press, 1981.

NISSA, Gregório de. Vita Moïse. Paris: Éditions du Cerf, 2000.

ORÍGENES. De principiis. In: A. CLEVELAND COXE, D.D (org.). Fathers of the Third Century. Grand Rapids: W. M. Eerdmans Publishing Company, 2001. (AnteNicene Fathers, V.4).

ORÍGENES. De principiis. In: SCHAFF, Phillip (Ed.). Commentarium in Iohannes e epist. ad greg. Grand Rapids: W. M. Eerdmans, 2001. (Ante-Nicene Fathers, v.8).

ORÍGENES. De principiis: contra Celsus. In: A. CLEVELAND COXE, D.D. Fathers of the Third Century. Grand Rapids: W. M. Eerdmans Publishing Company, 2001. (Ante-Nicene Fathers, v.4).

REALE, Giovanni. História da filosofia antiga. São Paulo: Loyola, 1994.

SESBOÜÉ, Bernard (Dir.). História dos dogmas: o Deus da salvação. São Paulo: Loyola, 2002.

SILVA, F. L. Teoria e modo de vida: filosofia e cristianismo. Agnes Cadernos de Pesquisa Em Teoria da Religião, São Paulo, v. 1, p. 35-48, 2004.

STRAUSS, Leo. Spinoza's critique of religion. Chicago: Chicago Univ. Press, 1997. 